\title{
Türkiye'de Üniversite Öğrenimi Gören Ahıskalı Öğrencilerin Yaşam Doyumlarının Demografik Değişkenler Açısından İncelenmesi
}

DOI: 10.26466/opus. 612655

\author{
* \\ Mihriban Kazımoğlu* - Nagihan Oğuz Duran** \\ * Psikolojik Danışman., Bursa Uludağ Üniversitesi, Eğitim Fakültesi, Görükle/Bursa / Türkiye \\ E-Posta: mhrban.kazmoglu@gmail.com \\ ORCID: 0000-0002-6573-0667 \\ ** Doç. Dr., Bursa Uludağ Üniversitesi, Eğitim Fakültesi, Görükle/Bursa/Türkiye \\ E-Posta: nagihan@uludag.edu.tr \\ ORCID: 0000-0002-8049-1510
}

$\ddot{O} z$

Türkiye'de üniversite öğrenimi gören çok sayıda Ahıskalı öğrenci bulunmaktadır. Bu öğrencilerin psikolojik durum ve ihtiyaçlarının belirlenmesi, yükseköğretimde psikolojik danışma ve rehberlik hizmetlerinin planlanması ve uygulanması bakımından önem taşımaktadır. Bireyin yaşamına ilişkin algı ve değerlendirmelerinden oluşan "yaşam doyumu", bu kapsamda önem taşıyan kavramlar arasında yer almaktadır, çünkü araştırmalar yaşam doyumunun arttırılması halinde çok sayıda olumlu psikolojik, sosyal, bedensel ve akademik çıktı elde etmenin mümkün olduğunu göstermektedir. Bu bakımdan, bu araştırmada: Türkiye'deki Ahıskal üniversite öğrencilerinin yaşam doyumların çeşitli demografik değişkenlerle ilişkileri bakımından inceleyerek, bu konudaki olası müdahale çalışmalarına ışık tutmak amaçlanmıştır. Bu amaçla, Türkiye'de 15 ayrı devlet üniversitesine öğrenimlerine devam eden 307 öğrenciden veri toplanmıştır. Verilerin toplanmasında Yaşam Doyumu Ölçeği'nin (YDÖ) yanı sıra Kişisel Bilgi Formu kullanılmıştır. Öncelikle, YDÖ'nün Türkiye'deki Ahıskalı üniversite öğrencileri için geçerlik ve güvenirliği incelenmiş ve ölçeğin bu grup için 5 maddelik tek boyutlu orijinal modele iyi uyum verdiği ve iç tutarlığının iyi olduğu görülmüştür. YDÖ puanlarında cinsiyete, ailenin yaşadığı yere ve aile üyeleri dışında vakit geçirilen kişilere göre anlamlı bir farklılık olmadığı, ancak, Türkiye'de eğitime başlama kademesine göre, ilkokulda başlayanlar ile ortaokul-lisede başlayanlar arasinda, ilk grubun lehine anlaml bir fark olduğu bulunmuştur. Son olarak, yaşam doyumu ve Türkiye'de yaşama süresi arasında anlamlı bir ilişki bulunmamıştır.

Anahtar Kelimeler: Ahıska Türkü, üniversite öğrencisi, yaşam doyumu 


\title{
Investigation of Life Satisfaction of Ahiska students in Turkish Universities in Regard to Demographic Variables
}

\begin{abstract}
There are many Ahiska students studying at universities in Turkey. Determining the psychological status and needs of these students is important for planning and implementing counseling and guidance services in higher education. "Life satisfaction" is among the important concepts in this context, since research findings show the possibility to obtain a number of positive psychological, social, physical, and academic outputs with an increase in one's life satisfaction. In this regard, this study aimed to shed light on possible interventions on this subject by examining the relationship between life satisfaction of Ahiska students in Turkey with various demographic variables. With this purpose, data were collected from 307 students attending at 15 different Turkish state-funded universities. A Personal Information Form and the Satisfaction With Life Scale (SWL) were used in data collection. First, the validity and reliability of the SWLS that previously validated on Turkish university students were examined for Ahiska students attending at Turkish universities. Results revealed that the SWLS showed a good fit to the original 5 item model for Ahiska students, and has good internal consistency. There was no significant difference on the SWLS scores in terms of gender, the place of residence of the family, and the people with whom the students spent time together, except family members. Ahiska students who started schooling in Turkey at elementary level scored significantly higher on the SWLS than students started schooling at middle and high school. Finally, life satisfaction was not significantly correlated with length of stay in Turkey.
\end{abstract}

Keywords: $\quad$ Ahiska Turks, university students, life satisfaction 


\section{Giriş}

Ahıska, Gürcistan'ın güneyinde, Türkiye'nin Ardahan ili sınırında bulunan ve 1578 yılında Osmanlı Devleti'nin Gürcistan'1 ilhak etmesinden sonra Osmanlı yönetiminde 250 yıl Türk vatanı olarak kalan bir bölgedir. Bu uzun dönem boyunca çeşitli özellikleri bakımından Anadolu'nun bir parçası olmuş ve Osmanlı belgelerinde Ahıska İli olarak yer almış olan bölgenin, 1828-29 Osmanlı Rusya savaşında Ruslara bırakılmasının ardından, Ahıska Türkleri için günümüze kadar gelen çeşitli sürgünler, göçler ve sıkıntılarla dolu bir süreç başlamıştır (Galiyeva, 2012).

1853-56 Osmanlı Rus savaşında Osmanlı yanlısı olmakla suçlanan Ahıskalıların gördükleri ceza ve işkenceler karşısında Erzurum'a sığınmalarından sonra, 1877-78 savaşında Osmanlı'nın yenilmesi üzerine daha büyük gruplar halinde Anadolu'ya göç ettikleri görülmüştür (Zeyrek, 2001). Göç etmeyerek baskı ve ayırımcllıklara rağmen kalanlar ise II. Dünya Savaşı döneminde Stalin tarafından "tehlikeli halklar" olarak adlandırılmış ve 14 Kasım 1944'te o dönemde Sovyet Sosyalist Cumhuriyetler Birliği (SSCB) üyesi olan Gürcistan'dan, Orta Asya'ya sürülmüştür (Ağara, 2004; Bayraktar, 1999; Ganiyeva, 2012; Seferov ve Akış, 2008; Zeyrek, 2001). Bu sürgünde büyük çoğunluğu Özbekistan'a gönderilen (Bayraktar, 1999) Ahıska Türkleri ile Özbekler arasında, SSCB'nin politikaları sonucunda husumet baş göstermesi nedeniyle buradaki Ahıska Türkleri tehdit edilmeye, dişlanmaya ve kendilerine iş verilmemeye başlamıştır. 1989 yılında Ahıska Türklerinin çoğunlukla yaşadığı Fergana'da çıkan olayların kısa sürede büyümesi ile (Agara, 2004; Aslan, 1995), Özbekistan'da birçok Ahıska Türkü evlerinin yakılıp yıkılmasına, çeşitli işkencelere, yaralanma veya ölüm olaylarına şahit olmuş ve/veya bunları deneyimlemiştir. Fergana olaylarının ardından 100 binden fazla Ahıska Türkü yeniden sürgüne gönderilmiştir (Seferov ve Ayhan, 2005).

Ahıska Türkleri her dönemde Türkiye'ye gelmeyi denemiş, gerek bireysel olarak gerekse iskân yasaları ile Türkiye'ye göç etmişlerdir. Göç edilecek yer olarak Türkiye'yi tercih etmelerinde özellikle çocukları ve kendileri için sosyal ve kültürel boyutlarda taşıdıkları gelecek kaygıları etkili olmuştur (Yılmaz ve Mustafa, 2014). Temmuz 1992 tarihinde Ahıska Türklerinin Türkiye'ye kabulü ve iskânına dair çıkan 3835 sayılı kanun, 
dünyanın çeşitli ülkelerinde yaşamlarını sürdüren Ahıska Türklerinin Türkiye'ye göçleri konusunda teşvik edici bir rol oynamıştır. Kanunun kabulü ile birlikte Türkiye'ye kabul edilen Ahıska Türklerinden ilk 200 aile Iğdır'a yerleştirilmiştir. Bu ilk yerleştirilenlerin ardından gelenler daha çok kendi olanakları ile başta Bursa, İstanbul ve Ankara olmak üzere büyük kentlere yerleşmişlerdir (Yılmaz ve Mustafa, 2014).

Sürgün, göç ve sıkıntılarla geçen yılların Ahıska halkının psikolojik yaşantıları üzerinde izler bırakması kaçınılmaz görünmektedir. Alanyazına göre, özellikle uluslararası göçler çok yönlü uyum sorunlarını da beraberinde getirir (Akıncı, Nergiz ve Gedik, 2015). Göçmenlerin yaşamış olduğu sosyal izolasyon (Victor, Scambler, Bond ve Bowling, 2000) ve kültürel şok (Ilgar ve Ilgar, 2015), alışkın oldukları değerler sistemi (Yıldırım, 2007) ve bu değerler sistemi ile bağlantılı olarak düşünülebilecek dil ve din farklılıkları (Bingöl ve Özdemir, 2014) göç edilen topluma uyum sürecini zorlaştıracak etkenler arasında sayılmaktadır.

Buna karşın göçün olumsuz etkilerini ortadan kaldırmada destek olabilecek etkenler de bulunmaktadır. Eğitim bu etkenler arasında önemli bir role sahiptir. Özellikle çocuk ve ergenler gibi yaşça daha küçük olan göçmenler için göçle gelinen ülkede eğitime devam etmenin, istismar edilme riskini ve psikolojik problemleri azaltmak ve psikolojik gelişimi desteklemek gibi koruyucu yararları bulunmaktadır (Nicholai ve Triplehorn, 2003; UNESCO, 2011). Ancak, yararlarına karşın eğitim, göçle birlikte ortaya çıan önemli problem alanlarından biri haline de gelebilmektedir (Börü ve Boyacı, 2016). Çeşitli araştırma bulguları, göçmen öğrencilerin gidilen ülkenin eğitim sistemi ile başarılı bir biçimde bütünleşememe (Tezcan, 1994) veya okul kültürü ile aile kültürünün örtüşmemesinden kaynaklanan uyum sorunları yaşayabildiklerini; bu öğrencilerin akademik başarılarının düşük, stres seviyelerinin yüksek olduğunu göstermektedir (Kincal, 2000). Göç-eğitim üzerine odaklanan çalışmalardan bazılarında ise özellikle çocukların yaşadığı ruhsal sıkıntılara değinilmiştir. Göçün çocuğun eğitimini olumsuz etkilediği (Kaştan, 2015), göç yaşamış çocuklarda ruhsal uyumsuzluk problemlerinin daha yüksek olduğu (Uluocak, 2009) bulgular arasındadır. Ayrıca, göç yaşamış çocuklarda daha fazla nevrotik bozukluk, okul başarısızlığ 1 ve tik, tırnak yeme vb. problemlerinin olduğu öğretmenleri tarafından bildirilmiştir (Bahar ve Yılmaz, 2018). 
Alanyazında, çeşitli zamanlarda, çeşitli nedenlerle Türkiye'ye göç etmiş farklı göçmen gruplarından öğrencilerin psikolojik gereksinimlerini ve bunlara yönelik müdahaleleri konu edinen araştırmalar bulunmakla birlikte, bu çalışmalar arasında Ahıskalı öğrencileri konu edinenlerin yok denecek kadar az olduğu görülmektedir. Göçmen öğrencilerin eğitsel ve psikolojik gereksinimlerinin belirlenmesi ve bu öğrenciler için psikolojik ve eğitsel destek sistemlerinin devreye sokulması önemli ve gerekli hale gelmektedir. İlköğretimden yükseköğretime kadar tüm eğitim kademelerindeki psikolojik danışma ve rehberlik (PDR) servislerine bu konuda görev düşmektedir. Bu öğrenci grubunun gereksinimini duyduğu hizmetlerin sağlanabilmesi, öncelikle bu konudaki sorunların ve bunların ilişkili olduğu değişkenlerin belirlenebilmesine bağlıdır.

Ahıska Türklerinin göç yaşantıları yukarıda açılandığı gibi uzun yıllar öncesinden başladığı için, bugün Türkiye'de yükseköğrenim düzeyindeki Ahıskalı öğrencilerin göçle ilişkileri bakımından durumları çeşitlilik göstermektedir. Bu öğrencilerin bir kısmı aileleri ile birlikte farklı bir ülkeye göç etme deneyimini yaşamış iken, bir kısmı kendileri göç yaşantısını deneyimlememiş, ancak eski göçmenlerin çocukları oldukları için bu deneyimden dolaylı olarak etkilenmiştir. Bir kısmı, aileleri de Türkiye'de bulunan ve zamanla yasal süreçler ile Türk vatandaşlı̆̆ına geçmiş bireyler iken, bir kısmı ise aileleri Türkiye dışındaki başka ülkelere göç etmiş ve halen oralarda yaşayan, kendileri ise Türkiye'de yabancı uyruklu öğrenci statüsünde yükseköğrenimlerine devam eden öğrencilerdir. Bu durumda, bu öğrencilerin kiminin göçmenlikle ilgili kiminin ise yükseköğrenimde yabancı uyruklu öğrenci olmakla ilgili sorun ya da ihtiyaçlarının olması muhtemeldir. Her iki durumda da Türk üniversitelerindeki Ahıskalı öğrencilerin durumlarının incelenmesi ve bunlara ilişkin gerekli önlem ve müdahalelere başvurulması önemlidir.

\section{Türkiye'deki Ahıskalı öğrenciler ve yaşam doyumu}

Yaşam doyumu; özellikle göç sonrası psikolojik uyumun incelenmesinde kullanılan önemli bir kavramdır (Ward ve Rana-Deuba, 1999). Alanyazında yaşam doyumunun gerek tanımlanmasında gerekse ölçülmesinde mutluluk düzeyi ile ilişkilendirildiği görülmektedir. Yaşam doyumu kişinin mutluluğa ilişkin sübjektif değerlendirmesini, yaşamını 
değiştirme arzusunu, yaşamının tümünü veya aile, arkadaşlar, bulunulan ortamlar vb. belli yaşam çevrelerinde mutluluğu kendi ölçütlerine göre incelemesini ifade etmektedir (Diener, Oishi ve Lucas, 2003). Buna göre yaşam doyumu, kişinin kendi hayatına dair değerlendirmeler ve temel bir kanıdan oluşmaktadır.

Bu değerlendirme ve kanının önem taşıdığ gruplardan birisi de üniversite öğrencileridir. Üniversite yılları öğrencilerin yetişkin hallerini deneyimledikleri, çalışma hayatına kendilerini hazırladıkları ve hayatlarına dair önemli hedefler oluşturdukları bir zamandır. On yedi farklı ülkeden katılımcılarla gerçekleştirilen bir araştırmanın da gösterdiği gibi (Diener, 2000), üniversite öğrencileri yaşam doyumu ve mutluluğu liselilere göre daha çok önemsemektedirler. Ayrıca, üniversite öğrencileri üzerinde yürütülen diğer bazı çalışmalarda yaşam doyumu ile benlik saygısı arasında pozitif yönde (Yetim, 2003); depresyon, umutsuzluk, durumluk ve sürekli kaygı ile negatif yönde (Gündoğar, Sallan-Gül, Uskun, Demirci ve Keçeci, 2007) ilişki olduğu ortaya konmuştur. Çeşitli araştırmalarda da, yüksek yaşam doyumunun psikolojik iyi oluş (Diener, 1994; Myers ve Diener, 1995), fiziksel sağlık (Roysamb, Tambs, ReichbornKjennerud, Neale ve Harris, 2003) ve daha yaratıcı ve üretken olma (Staw, Sutton ve Pelled, 1994) ile ilişkisi bildirilmiştir. Bu bakımdan, üniversite öğrencilerinde yaşam doyumunun artmasının, olumlu psikolojik sağlığın gerçekleşmesi bakımından önemli bir role sahip olduğu düşünülebilir.

Gerek göçmen gerekse yabancı uyruklu öğrenci olarak başka bir ülkede öğrenim gören öğrencilerin yaşadıkları kültürleşme sürecinin bu kişilerin yaşam doyumları üzerinde çeşitli etkilerinin olması beklenebilir. Kültürleşme, farklı kültürel alt yapılara sahip kişi ve gruplarla temas sonucu birey ve grup düzeyinde yaşanan kültürel ve psikolojik değişim sürecini ifade etmektedir (Berry, 1997; 2002). Alanyazında göçmenlerin günlük yaşamlarında meydana gelen değişimlerin onların yaşam doyumlarını olumsuz yönde etkileyebildiği bildirilmektedir (Şeker ve İbrahim, 2014). Benzer bir durumun göçmen olmasa da yabancı uyruklu öğrenci olarak başka bir ülkede öğrenim gören öğrenciler için de geçerli olacağı düşünülebilir.

Yaşam doyumu ve göçmenlik ilişkisini gösteren çeşitli araştırmaların bulguları da bu görüşü destekler niteliktedir. Örneğin, ötekileştirilmenin yaşam doyumu ile etkileşimini incelemek amacıyla Hollanda'da yapılan 
araştırmada Türk göçmenlerin yaşadığı ayrımcılığın yaşam doyumlarına negatif yönde etkilediği görülmüştür (Verkuyten, 2008) Ayrıca Vedder, Vijver ve Liebkind'ın (2006) 13 ayrı ülkede yaşayan 7000'i aşkın göçmenle gerçekleştirdikleri bir araştırmada hissedilen ayrımcılık ile yaşam doyumu negatif yönde ilişkili bulunmuştur. Türkiye'deki üniversitelerde öğrenim gören çok sayıda Ahıskalı öğrenci bulunmaktadır. Bu öğrencilerin psikolojik durum ve ihtiyaçlarının belirlenmesi, yükseköğretimde PDR hizmetlerinin planlanması ve uygulanması bakımından önem taşımaktadır. Bireyin yaşamına ilişkin algı ve değerlendirmelerinden oluşan "yaşam doyumu", bu kapsamda incelenebilecek kavramlar arasında yer almaktadır, çünkü araştırmalar yaşam doyumunun arttırılması halinde çok sayıda olumlu psikolojik, sosyal, bedensel, akademik vb. çıtı elde etmenin mümkün olduğunu göstermektedir. Bu bakımdan bu araştırmanın temel amacı: Türkiye'deki Ahıskalı üniversite öğrencilerinin yaşam doyumlarını çeşitli demografik değişkenlerle (cinsiyet, Türkiye'de eğitime başladıkları kademe, ailenin ikamet ettiği ülke (Türkiye- Türkiye dışı), aile dışında vakit geçirilen kişiler, Türkiye'de bulunma süresi) ilişkileri bakımından inceleyerek, bu konudaki olası müdahale çalışmalarına ışık tutmaktır.

\section{Yöntem}

\section{Çalışma Grubu}

Araştırmanın çalışma grubu, 2018-2019 akademik yılı bahar döneminde, Türkiye'deki 15 ayrı devlet üniversitesinde öğrenimlerine devam eden, yaşları 17-35 arasında değişen ( $\overline{X=21.45, ~ S S=2.46)}$ toplam 307 öğrenciden oluşmaktadır. Katılımcların \%49.8'i ( $n=152)$ kadın, \%50.2'si $(n=154)$ ise erkektir. Katılımcılara ilişkin demografik verilere Tablo 1'de yer verilmiştir.

Tablo 1'de görüldüğü gibi, araştırmaya katılan öğrencilerin cinsiyete göre dağılımı oldukça dengelidir. Sınıf düzeyi bakımından en fazla katılımcı 1. sinıf $(\% 34,9)$ öğrencilerinden oluşmakta, bunu sırasıyla 2.sınıf $(\% 27,7)$, 4.sinıf $(\% 19,2)$ ve 3.sınıf $(\% 18,2)$ öğrencileri izlemektedir. Araştırmaya katılan öğrencilerin aileleri dışında en çok kimlerle vakit 
geçirdiklerine bakıldığında, çoğunun (\% 61,9) hem Ahıskalılar hem de Ahıskalı olmayanlarla vakit geçirdikleri görülmüştür.

Tablo 1. Demografik Veriler

\begin{tabular}{llll}
\hline Demografik Özellik & & $\mathrm{n}$ & $\%$ \\
\hline \multirow{2}{*}{ Cinsiyet } & Erkek & 154 & 50,2 \\
& Kadın & 153 & 49,8 \\
\hline \multirow{3}{*}{ Sinıf } & 1 & 107 & 34,9 \\
& 2 & 85 & 27,7 \\
& 3 & 56 & 18,2 \\
\multirow{2}{*}{ Aile dişında daha çok kim- } & Ahıskalılar ile & 59 & 19,2 \\
\multirow{2}{*}{ lerle vakit geçirildiği } & Ahiskalı Olmayanlar ile & 28 & 9,1 \\
& Her ikisi ile & 89 & 29 \\
\multirow{2}{*}{ Ailenin ikamet ettiği yer } & Türkiye'de yaşayanlar & 190 & 61,9 \\
& Türkiye dişında yaşayanlar & 127 & 58,6 \\
& İlkokul & 108 & 31,4 \\
\hline \multirow{2}{*}{ Türkiye'de eğitime } & Ortaokul-Lise & 60 & 19,5 \\
başlanılan kademe & Yükseköğretim & 139 & 45,3 \\
\hline
\end{tabular}

Çoğunlukla Ahıskalı olmayanlar ile vakit geçirenler (\%29) çoğunlukla Ahıskalılar ile vakit geçirenlerden $(\% 9,1)$ daha fazladır. Ailelerinin ikamet ettiği yer bakımından, katılımcıların yarıdan biraz fazlasını $(\% 58,6)$ ailesi Türkiye'de yaşayanlar oluşturmuştur. Türkiye'de eğitime başladıkları kademe bakımından ise en fazla sayıda katılımcının (\%45,3) yükseköğretim düzeyinde başladıklarını bildirdiği, bunu ilkokulda başladıklarını bildirenlerin $(\% 35,2)$ izlediği görülmüştür. Araştırmaya katılan öğrenciler arasında Türkiye'deki eğitimlerine "ortaokulda" ve "lisede" başladıklarını bildirenlerin sayısının az olması nedeniyle, istatistiksel analizlere uygun olması bakımından bu iki grup birleştirilerek "ortaokul-lisede" biçiminde yeni bir grup yaratılmıştır $(\% 19,5)$.

\section{Veri Toplama Araçları}

Yaşam Doyum Ölçeği (YDÖ): Çalışmada Deiner ve arkadaşlarının (1985) geliştirdiği YDÖ kullanılmıştır. YDÖ'de yaşam doyumunu ölçmeye yönelik beş soru yer almaktadır; ters puanlanan madde ise bulunmamaktadır. YDÖ'den alınan yüksek puanlar yüksek yaşam doyumu anlamına gelmektedir. Diener ve arkadaşlarının (1985) çalışmasında ölçeğin 
Cronbach Alpha iç tutarlık katsayısı ,87 olarak, YDÖ puanlarının ölçümü puanları ile karşılaştırılmasına dayanan ölçüt bağımlı geçerliği ise $r=, 85$ olarak tespit edilmiştir. YDÖ'nün bu araştırmada kullanılan Türkçe sürümü, Dağlı ve Baysal (2016) tarafından geliştirilmiştir. Uyarlama çalışmasında Türkçe YDÖ'nün orijinal ölçekte olduğu gibi 5 maddelik tek faktörlü bir yapı gösterdiği, Cronbach Alpha iç tutarlık kat sayısının ,88, test- tekrar test güvenirliğinin ise, 97 olduğu bulunmuştur.

\section{YDÖ’nün Ahıskalı Öğrenciler için Geçerlik ve Güvenirliği}

\section{Yapı Geçerliği için Yapılan DFA Sonuçlan}

Kültürlerarası ölçek uyarlama çalışmalarında, aracın orijinal faktör desenini hedef kültürde de koruyup korumadığını incelemek için DFA yapılması önerilmektedir (Çokluk, Şekercioğlu ve Büyüköztürk, 2010). Bu nedenle, bu araştırmada YDÖ'nün önceden belirlenmiş olan tek faktörlü yapısını test etmek amacıyla DFA uygulanmıştır. DFA sonuçlarının geçerli kabul edilebilmesi için modele ait bazı uyum indekslerinin iyi veya kabul edilebilir düzeyde olması gerekmektedir. Buna ilişkin alan yazında yer alan bazı ölçütler Tablo 2'deki gibidir.

Tablo 2. Standart Uyum Ölçüleri

\begin{tabular}{lll}
\hline Uyum ölçütleri & Kabul edilebilir değerler & En iyi değerler \\
\hline NFI & $0,90-0,95$ & $0,95-1,00$ \\
GFI & $0,90-0,95$ & $0,95-1,00$ \\
CFI & $0,95-0,97$ & $0,97-1,00$ \\
RMSEA & $0,05-0,08$ & $0,00-0,05$ \\
\hline
\end{tabular}

Schermelleh-Engel ve Moosbrugger (2003)

$\mathrm{Bu}$ araştırmada YDÖ için Ahıskalı üniversite öğrencilerinden elde edilen veriler için yapılan DFA sonucunda modele ilişkin uyum indeksleri $\mathrm{CFI}=$,98; $\mathrm{GFI}=$,99 ve NFI= ,97; RMSEA= ,04 olarak bulunmuştur. Ayrica Ki-Kare serbestlik derecesi oranının ( $\chi 2 / \mathrm{df})$ 3'ün altında olması koşulu (Sümer, 2000) aranmış ve bu değer de çalışmada 2,87 olarak hesaplanmıştır. Buna göre, bu çalışmada DFA ile hesaplanan değerler önerilen faktör modelinin veriler ile iyi uyum gösterdiğini, bir başka ifadeyle YDÖ'nün Türkiye'deki Ahıskalı üniversite öğrencilerinde 
kullanılmak üzere 5 maddelik tek-boyutlu yapısı ile geçerli bir ölçme aracı olduğunu ortaya koymuştur. Yapılan DFA sonucu elde edilen yol diyagramı Şekil 1'de verilmiştir

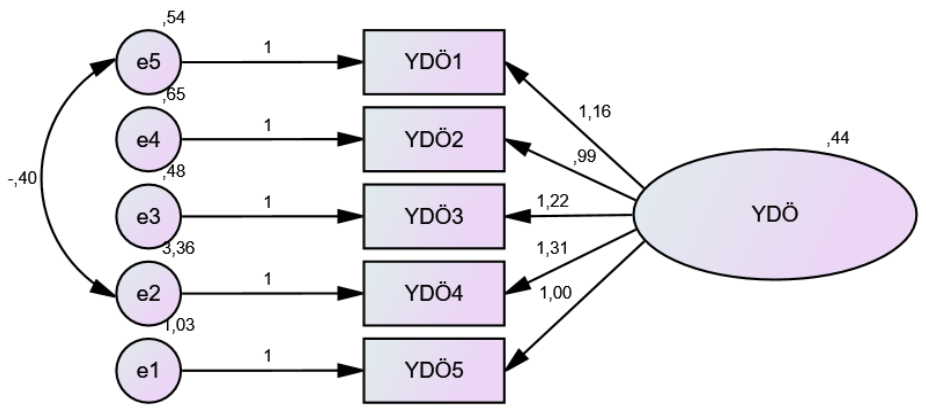

Şekil 1. DFA sonucunda elde edilen Yol Diyagramı

\section{Güvenirlik analizlerinin sonuçları}

Araştırmada YDÖ'nün güvenirliliğini incelemek üzere öncelikle Cronbach Alpha iç tutarlılık katsayısı hesaplanmıştır. Bu değer $\alpha=, 68$ olarak bulunmuştur. Ayrıca YDÖ'nün madde-toplam puan korelasyonları hesaplanmış ve sonuçlar Tablo 3'te verilmiştir. Madde toplam korelasyonları incelendiğinde tüm maddelerin madde toplam korelasyon değerlerinin $0,30^{\prime}$ dan yüksek olduğu görülmektedir. Alanyazında ,60' ın üzerindeki Cronbah $\alpha$ değerleri (Yıldız ve Uzunsakal, 2018).) ve ,30'un üzerindeki madde-toplam puan korelasyonları (Büyüköztürk, 2004) kabul edilebilir bulunduğundan, YDÖ Türkiye' de yükseköğrenime devam eden Ahıskalı öğrencilerde kullanılmak üzere güvenilir bir ölçme aracı olarak değerlendirilmiştir.

Tablo 3. Madde-Toplam Puan Korelasyonlarn

\begin{tabular}{cccc}
\hline Maddeler No & $\overline{\boldsymbol{X}}$ & SS & Madde-Toplam Korelasyonu \\
\hline 1. & 3,17 & 1,06 &, 464 \\
2. & 3,08 & 1,04 &, 556 \\
3. & 3,45 & 1,06 &, 607 \\
4. & 3,37 & 2,03 &, 314 \\
5. & 2,85 & 1,21 &, 450 \\
\hline
\end{tabular}




\section{İşlem}

YDÖ'nün Türkiye'deki Ahıskalı üniversite öğrencilerinde kullanılmak üzere geçerlik ve güvenirliğinin incelenmesi amacıyla öncelikle ölçeği Türkçe'ye uyarlayan Dağlı (2016)'dan elektronik posta yolu ile izin alınmıştır. Ardından ölçme araçları, elektronik ortama aktarılarak "Google Formlar" üzerinden uygulamaya hazır hale getirilmiş ve sosyal medya aracılığı ile paylaşılarak araştırmaya katılmaya gönüllü olan 163 öğrenci tarafından bu yolla yanıtlanmıştır. Ayrıca, katılımcı sayısını arttırabilmek amacıyla 5 ayrı üniversitede 200 öğrenciye ölçme araçları elden dağıtılarak veri toplanmıştır. Sonuç olarak, tüm veriler, 2018-2019 akademik yılı bahar döneminde, Türkiye'deki 15 ayrı devlet üniversitesinde öğrenimlerine devam eden Ahıskalı öğrencilerden elde edilmiştir.

\section{Veri Analizi}

Çalışma verileri SPSS 22 ve AMOS 23 programları kullanılarak analiz edilmiştir. Veri analizinde, öncelikle aritmetik ortalama, standart sapma, yüzdelik ve frekans vb. betimleyici istatistikler hesaplanmıştır. YDÖ’nün yapı geçerliliği doğrulayıcı faktör analizi (DFA) ile güvenirliği ise Cronbach Alfa iç tutarlılık katsayısı ve madde toplam puan korelasyonları ile değerlendirilmiştir. Sürekli değişkenler için iki bağımsız grubun karşılaştırılmasında $t$ testi, üç bağımsız grubun karşılaştırılmasında Varyans Analizi (ANOVA) kullanılmıştır. Değişkenler arası ilişkileri incelemek amaciyla Pearson Momentler korelasyon katsayıları hesaplanmıştır. Çalışmada istatistiki anlamlılık değeri $\mathrm{p}<, 05$ olarak kabul edilmiştir.

\section{Bulgular}

Türkiye'deki Ahıskalı üniversite öğrencilerinin yaşam doyumlarının çeşitli demografik değişkenlere göre incelenmesine ilişkin bulgular

Araştırmada Türkiye'deki Ahıskalı üniversite öğrencilerinin yaşam doyumları cinsiyete, ailelerinin ikamet ettiği yere, aileleri dışında en çok vakit geçirdikleri kişilere, Türkiye'de eğitime başladıkları kademeye ve 
Türkiye'de yaşama sürelerine göre incelenmiş ve sonuçlara aşağıda sırasıyla yer verilmiştir.

\section{YDÖ puanlarının cinsiyete göre incelenmesine ilişkin bulgular}

YDÖ puanlarında katılımcılarının cinsiyetlerine göre anlamlı bir farklılık olup olmadığı bağımsız örneklem t-testi kullanılarak hesaplanmış, sonuçlar Tablo 4'te verilmiştir.

Tablo 4. YDÖ puanlarının cinsiyete göre incelenmesine ilişkin t testi sonuçları

\begin{tabular}{lllllllr}
\hline & Cinsiyet & $\mathbf{N}$ & $\overline{\boldsymbol{X}}$ & $\mathbf{S S}$ & $\mathbf{S D}$ & $\mathbf{t}$ & $\boldsymbol{p}$ \\
\hline YDÖ & Erkek & 154 & 16,18 & 4,68 &, 305 & \multirow{2}{*}{, 966} & \multirow{2}{*}{, 335} \\
& Kadın & 153 & 15,69 & 4,16 & & & \\
\hline
\end{tabular}

Tablo 4'te görüldüğü gibi, YDÖ puanlarında cinsiyete göre anlamlı bir farklılık bulunmamıştır. Buna göre, Türkiye' de üniversite öğrenimi gören Ahıskalı erkek $\left(x^{-}=16,18, \mathrm{SS}=4,68\right)$ ve kadın $\left(x^{-}=15,69, \mathrm{SS}=4,16\right)$ öğrencilerin yaşam doyumu düzeyleri benzerdir.

YDÖ puanlarının ailenin ikamet ettiği yere göre incelenmesine ilişkin bulgular

YDÖ puanlarının öğrencilerin ailelerinin ikamet ettiği yere göre incelenmesi amacıyla bağımsız örneklemler t-testi uygulanmış ve sonuçlar Tablo 5 'te verilmiştir.

Tablo 5. YDÖ puanlarının ailenin ikamet ettiği yere göre incelenmesine ilişkin t-testi sonuçları

\begin{tabular}{clccccc}
\hline Puan & Ailenin Yaşadığı yer & $\mathbf{n}$ & $\boldsymbol{X}^{-}$ & SS & $\mathbf{t}$ & $\boldsymbol{p}$ \\
\hline \multirow{2}{*}{ YDÖ } & Türkiye & 180 & 15,96 & 4,42 &, 011 &, 918 \\
& Türkiye Dışı & 127 & 15,91 & 4,47 & & \\
\hline
\end{tabular}

Tablo 5 'te görüldüğü gibi ailesi Türkiye' de yaşayan $\left(x^{-}=15,96, \mathrm{SS}=4,42\right)$ ve yaşamayan $\left(x^{-}=15,91, \mathrm{SS}=4,47\right)$ Ahıskalı öğrencilerin yaşam doyumu düzeyleri arasında anlamlı bir farklılık bulunmamıştır $(p=, 918)$. Buna 
göre, ailelerinin Türkiye'de ya da Türkiye dışındaki ülkelerde ikamet etmesi Türkiye'deki üniversitelerde öğrenim gören Ahıskalı öğrencilerin yaşam doyumu düzeyleri üzerinde anlamlı bir farklılık yaratmamaktadır.

\section{YDÖ puanlarının aile dışında vakit geçirilen kişilere göre incelen- mesine ilişkin bulgular}

Türk üniversitelerinde eğitim gören Ahıskalı öğrencilerin yaşam doyumu düzeylerinin aile dışında vakit geçirdikleri kişilere göre incelenmesi için ANOVA uygulanmış ve sonuçlar Tablo 6' da verilmiştir.

Tablo 6. YDÖ puanlarının aile dışında vakit geçirilen kişilere göre incelenmesine ilişkin ANOVA sonuçları

\begin{tabular}{llrcccc}
\hline & Kademe & N & $\bar{X}$ & SS & F & $p$ \\
\hline \multirow{3}{*}{ YDÖ } & Ahiskalılar ile & 28 & 15,50 & 4,22 &, 290 &, 748 \\
& Ahiskalı olmayanlar ile & 89 & 15,78 & 4,17 & & \\
& Her ikisi ile & 190 & 16,08 & 4,59 & & \\
\hline${ }^{*} p>05$ & & & & &
\end{tabular}

Tablo 6'da görüldüğü gibi, Ahıskalı öğrencilerin aile dışında vakit geçirdikleri kişilere göre YDÖ puanları arasında anlamlı bir farklılık bulunmamıştır $[F(2,304)=2,90, p=, 748]$. Buna göre aile üyeleri dişında Ahıskalılarla, Ahıskalı olmayanlarla veya Her ikisiyle vakit geçirenlerin yaşam doyumları arasında anlamlı bir farklılık yoktur.

\section{YDÖ puanlarının Türkiye'de eğitime başlanan kademeye göre incelen- mesine ilişkin bulgular}

Türk üniversitelerinde eğitim gören Ahıskalı öğrencilerin yaşam doyumu düzeylerinin Türkiye'de eğitimlerine hangi kademeden başladıklarına göre incelenmesi için ANOVA uygulanmış ve sonuçlar Tablo 7'de verilmiştir.

Tablo 7'de görüldüğü gibi, Ahıskalı öğrencilerin Türkiye'de eğitme başladıkları kademelere göre YDÖ puanları bakımından anlamlı bir farklılık bulunmuştur $[\mathrm{F}(2 ; 304)=5,47, \mathrm{p}<, 01)$. Levene testinin sonucu, YDÖ puanlarının varyanslarının homojenliğini gösterdiğinden $(\mathrm{L}=, 244 \mathrm{p}=$ 
,783), Türkiye'de eğitime başlanılan kademeye göre YDÖ puanlarındaki anlamlı farkın kaynağını bulmak amacıyla Scheffe testi uygulanmıştır

Tablo 7. YDÖ puanlarının Türkiye'de eğitime başlama kademesine göre incelenmesine ilişkin ANOVA sonuçları

\begin{tabular}{llccccc}
\hline & Kademe & N & \multicolumn{1}{c}{ SS } & SS & F & $p$ \\
\hline \multirow{4}{*}{ YDÖ } & İlkokul & 108 & 16,97 & 4,01 & & \\
& Ortaokul-Lise & 60 & 14,76 & 4,49 & & \\
& Üniversite & 139 & 15,65 & 4,57 & 5,47 &, 005 \\
\hline
\end{tabular}

${ }^{*} p<.01$

Sonuçlar, Türkiye'de eğitimine ilkokul $(\overline{X=16,97 ;} S S=4,01)$ ve ortaokullise $(\overline{X=14,76 ;} \mathrm{SS}=4,49)$ kademelerinde başlayanlar arasında birinci grubun lehine anlamlı bir farkın bulunduğunu $(\mathrm{p}<, 05)$ göstermiştir. Buna göre, Türkiye'deki eğitimlerine ergenlik yıllarına denk gelen ortaokul-lise kademelerinde başlayan Ahıskalı öğrencilerin yaşam doyumlarının ilkokul düzeyinde başlayanlara göre anlamlı düzeyde daha düşük olduğu söylenebilir.

\section{YDÖ puanlarının Türkiye'de yaşama süresi ile ilişkisinin incelen- mesine ilişkin bulgular}

Türk üniversitelerinde eğitim gören Ahıskalı öğrencilerin yaşam doyumu düzeylerinin Türkiye'de yaşadıkları süre ile ilişkisi pearson momentler korelasyon analizi ile incelemiştir. Sonuç olarak, Ahıskalı öğrencilerin Türkiye' de bulundukları süre ile (yıl) yaşam doyumları arasında anlamlı bir ilişkisinin bulunmadığ $(r=, 03 ; p=, 07)$ görülmüştür.

\section{Tartışma, Sonuç ve Öneriler}

Bu araştırmada Türkiye'deki Ahıskalı üniversite öğrencilerinin yaşam doyumlarını çeşitli demografik değişkenlerle (cinsiyet, ailenin ikamet ettiği yer, aile dışında vakit geçirilen kişiler, Türkiye'de eğitime başlanan kademe, Türkiye'de yaşama süresi) ilişkileri bakımından inceleyerek, bu konuda yürütülebilecek olası müdahale çalışmalarına ışık tutmak amaçlanmıştır. Araştırmada öncelikle bu öğrencilerin yaşam 
doyumlarının cinsiyete göre anlamlı bir farklılık göstermediği bulunmuştur. Buna göre, Ahıskalı üniversite öğrencilerinin yaşam doyumu düzeyleri kadın veya erkek olmaları bakımından farklılaşmamaktadır. Bu bulgu, alanyazındaki üniversite öğrencilerinin yaşam doyumunun cinsiyete göre farklılaşmadığ 1 yönündeki geçmiş araştırmaların bulguları ile uyumludur (Şahin, 2018; Kermen,İlçin Tosun ve Doğan, 2016 ).Alanyazında gerek Türkiye'de gerekse Dünya'da yaşam doyumunun kadınlarda ya da erkeklerde daha yüksek olduğunu gösteren çalışma bulgularına rastlansa da (Köker, 1991; Mayungbo, 2016; Moksnes ve Espnes, 2013) yaşam doyumu üzerindeki cinsiyet etkisinin kültürel ve sosyal çok sayıda faktörle ilişkili olduğu bilinmektedir (Huebner, 2004). Bu bakımdan, Türkiye'deki Ahıskalı üniversite öğrencilerinin yaşam doyumu düzeyleri üzerinde tek başına cinsiyetin belirleyici olmadığı söylenebilir.

Ailelerinin Türkiye'de veya Türkiye dışında yaşamasının Ahıskalı öğrencilerin yaşam doyumu puanlarında anlamlı bir fark yaratmadığı bu araştırmada elde edilen bir başka bulgudur. Türkiye' deki Ahıskalı üniversite öğrencileri üzerinde daha önce Kemal ve Oğuz Duran (2019)'ın yapmış oldukları bir çalışmada da, ailelerinin Türkiye'de veya Türkiye dışındaki ülkelerde yaşamasının bu öğrencilerin psikolojik sağlamlık ve mutluluk düzeylerinde anlamlı bir farklılık yaratmadığı bulunmuştur. Alanyazında, bireylerin ailelerinin yanında bulunmasının bir manevi destek oluşturarak bireylere özgüven (Bilge, Dost ve Çetin, 2014) ve akademik başarı (Çalışkan ve Ayık, 2015) vb. alanlarda avantajlar sağladığı bildirilmektedir. Ancak söz konusu çalışmaların hedef kitlesinin yükseköğrenim öğrencilerinden oluşmadığ1 görülmektedir. Bu araştırmada, gelişimsel olarak genç yetişkinlik evresinde bulunan üniversite öğrencilerinden oluşan katılımcı grubu için aileleri ile aynı ülkede yaşayıp yaşamamanın yaşam doyumu üzerinde anlamlı bir farklılık yaratmadığı bulunmuştur. İçinde bulundukları gelişim dönemi gereği, Ahıskalı öğrencilerin ailelerinin yanlarında bulunmamasından anlamlı biçimde etkilenmemiş olması anlaşılabilir bir sonuç olarak düşünülebilir.

$\mathrm{Bu}$ araştırmanın bulgularına göre, Türkiye'deki Ahıskalı üniversite öğrencilerinin büyük bölümü (\%61.9) aileleri dışında vakit geçirdikleri kişileri Ahıskalılar ve Ahıskalı olmayanlardan oluşan karma bir grup 
olarak tanımlamıştır. Ahıskalı öğrencilerin en çok kimlerle vakit geçimeyi tercih ettiklerine ilişkin bu bulgu, bu konuda daha önce gerçekleştirilmiş bir araştırma bulgusuna rastlanmaması nedeniyle, alanyazına bir katkı olarak görülmüştür. Ayrıca, aynı bulgunun devamı olarak katılımcılar arasında \%9'luk bir grubun çoğunlukla kendileri gibi Ahıskalılarla birlikte vakit geçirmeyi tercih ettikleri de görülmüş ve bunun nedenlerinin başka araştırmalarda incelenmesinde yarar görülmüştür. Bununla birlikte, bu araştırmada çoğunlukla Ahıskalılarla, Ahıskalı olmayanlarla ve her ikisiyle vakit geçirenler arasında yaşam doyumu düzeyi bakımından anlamlı bir farklılık bulunmamıştır. Bu durum Ahıskalı öğrencilerin Türkiye'deki akranları ile iyi uyum sağlamış olmalarının bir belirtisi olarak düşünülebilir ve Ahıska Türklerlerinin Türkiye ile tarihi ve kültürel ortak paydaları ile açıklanabilir.

Araştırmada Ahıskalı üniversite öğrencilerinin yaşam doyum düzeylerinin Türkiye'deki eğitimlerine hangi eğitim kademesinden başladıkları bakımından anlamlı bir fark gösterdiği bulunmuştur. Alanyazında daha önce Dursun ve Oğuz Duran (2019) tarafından yapılan bir araştırmada da Türkiye'deki Ahıskalı üniversite öğrencilerinin psikolojik dayanıklılık düzeylerinin Türkiye'de eğitime başladıkları kademeye göre anlamlı biçimde farklılaştığı ve Türkiye' de eğitime ilkokul düzeyinde başlayanların psikolojik dayanıklılık puanlarının yükseköğretim düzeyinde başlayanlardan anlamlı derecede daha yüksek olduğu görülmüş, bu bulgu Türkiye'de eğitime ilkokul düzeyinde başlamanın, Ahıskalı öğrencilerin buradaki yaşama ve eğitim sistemine daha erken dönemde uyum sağlamaları üzerinde kolaylaştırıcı bir etki yapması ile açıklanmıştır. Bu çalışmada da benzer biçimde yaşam doyumu bakımından,Türkiye'deki eğitimlerine ilkokul düzeyinde başlayanların lehine anlamlı bir fark görülmüsstür. Ancak bu fark yükseköğretim düzeyinde başlayanlarla değil ortaokul-lise düzeyinde başlayanlarla ortaya çıkmıştır. Buna göre, ergenlik yıllarına denk gelen ortaokul ve lise yıllarında Türkiye'deki eğitimlerine başlayan Ahıskalı öğrenciler, ilkokulda başlayanlara göre yaşam doyumu bakımından dezavantajlı görünmektedir. Bu bulgu, ergenlik yıllarında Türkiye'de eğitimlerine başlayan Ahıskalı öğrenciler için önleyici PDR hizmetlerinin gereğine işaret etmiştir. 
Son olarak, araştırmada Ahıskalı öğrencilerin Türkiye'de yaşama süreleri ile yaşam doyum düzeyleri arasında anlamlı bir ilişki bulunmamıştır. Bu bulgu daha önce Türkiye'deki Ahıskalı üniversite öğrencileri üzerinde yapılan iki ayrı çalışmanın (Dursun ve Oğuz Duran, 2019; Kemal ve Oğuz Duran, 2019) bulgulariyla da uyumludur. Türkiye'de yaşama süresi daha önce Ahıskalı öğrencilerin mutluluk, psikolojik sağlamlık ve psikolojik dayanıklılık düzeyleri ile anlamlı biçimde ilişkili bulunmadığı gibi, bu araştırmanın bulgularına göre, yaşam doyumları ile de anlamlı bir ilişkisi içinde değildir. Başka bir deyişle, daha uzun ya da daha kısa süredir Türkiye'de yaşıyor olmak Ahıskalı öğrencilerin yaşam doyumlarını etkilememektedir. Bu bulgu, Ahıskalı öğrencilerin yaşam doyum düzeyinin yalnızca Türkiye'de yaşama süreleri ile açıklanamayacağı ve bunun dışındaki başka faktörlerden (bu ülkedeki yaşam koşulları, ekonomi, vb.) etkilenebileceği ile açıklanabilir.

Bu araştırmanın esas amacını oluşturmamakla birlikte, araştırma sonucunda alanyazına sağlanan bir katkı da Deiner ve arkadaşları (1985) tarafından geliştirilen ve Türk üniversite öğrencilerinde daha önce geçerlik ve güvenirlik çalışmaları yapılmış olan (Baysan ve Dağlı, 2016) YDÖ'nün Türkiye'de üniversite öğrenimi gören Ahıskalı öğrenciler için geçerlik ve güvenirliğinin incelenmesi olmuştur. YDÖ'nün yap1 geçerliğini incelemek amacıyla yapılan DFA sonuçları yapıya ait uyum indekslerinin $(\chi 2 / \mathrm{df}=2.87 ; \mathrm{GFI}=.99 ; \mathrm{CFI}=.98 ; \mathrm{NFI}=.97$; AGFI=.95; RMSEA= .04) iyi uyum gösterdiğini, iç tutarlığını incelemek amacıyla hesaplanan Cronbach alfa katsayısı $(\alpha=.68)$ ve madde-toplam puan korelasyonları YDÖ'nün Türkiye' deki üniversitelerde öğrenim gören Ahıskalı öğrenciler için kabul edilebilir düzeyde güvenilir bir ölçme aracı olduğunu göstermiştir. Bu bakımdan, bu araştırmanın Türkiye' deki Ahıskalı üniversite öğrencileri ile yürütülecek ilişkisel ve deneysel araştırmalarda ve bu öğrencilerin yaşam doyumlarının artırılmasına yönelik PDR hizmetlerinin etkinliğinin incelenmesinde kullanılabilecek bir ölçme aracının psikometrik özelliklerine ilişkin veri sağlayarak alanyazına katkıda bulunduğu düşünülmektedir.

$\mathrm{Bu}$ araştırmanın bulgularının alanyazına katkılarına karşın, araştırmada elde edilen sonuçlar bazı sınırlılıklar dâhilinde değerlendirilmelidir. Öncelikle, araştırmanın önemli sınırlılıklarından biri verilerin kolay 
ulaşılabilir örneklem alınarak ve kısmen internet aracılı̆̆ıyla toplanmış olmasıdır. Türkiye'de yükseköğrenime devam eden Ahıskalı öğrencileri daha iyi temsil edebilecek biçimde seçkisiz örnekleme yoluyla yapılacak benzer araştırmalarla bulguların genellenebilirliği artacaktır. Ayrıca bu çalışmanın bulgularının genellenebilirliği Türkiye'de üniversite öğrencisi olan Ahıskalılarla sınırlıdır ve bu nedenle Türkiye'deki diğer Ahıskalı öğrencilere genellenemeyeceği gibi, Türkiye dışındaki ülkelerde yaşayan Ahıskalı ögrrencilere de genellenemez. Bu bakımdan, Türkiye'de farklı eğitim kademelerindeki Ahıskalı öğrencilerin ve Türkiye dışındaki ülkelerde yaşayan Ahıskalı öğrencilerin yaşam doyumlarının araştııılması başka çalışmaların konusu olabilir. İkinci olarak, araştırmada kullanılan YDÖ'nün güvenirliğin incelenmesi için bu çalışmada yalnızca Cronbach Alpha ve madde-toplam puna korelasyonlarının hesaplanması yöntemlerine başvurulmuştur. Ölçeğin zamana bağlı kararlığını incelemeye yönelik test-tekrar test güvenirliğine bakılması başka çalışmaların konusu olabilir. 


\title{
EXTENDED ABSTRACT
}

\section{Investigation of Life Satisfaction of Ahiska students in Turkish Universities in Regard to Demographic Variables}

\author{
Mihriban Kazımoğlu - Nagihan Oğuz Duran \\ Bursa Uludağ University, Bursa Uludă̆ University
}

Ahiska region, located within the borders of Georgia, was a part of the Ottoman Empire for 250 years. However, this region was left to the Russians in 1828 as war reparations. From this date, Ahiska Turks experienced many emigrations and exiles for various reasons during Tsarist Russia and the Union of Soviet Socialist Republics (Ganiyeva, 2012; Zeyrek 2006). Currently they have lived in about 15 different countries around the world, and a number of Ahiskan people have preferred Turkey for settlement or education because of cultural and geographical proximity.

Since the migration of Ahiska Turks to Turkey began many years ago, there have been a number of Ahiska students, who are diverse in terms of their relationship to migration, studying at universities in Turkey. Some of these students had not experienced emigration themselves. They only indirectly were influenced by the emigration experience, since they were the children of former immigrants. Some of the Ahiskan students' families have been in Turkey. On the other hand, some of the students' families have been living in other countries. Some students become Turkish citizens through legal processes whereas others have not yet become Turkish citizens. As a result, some of Ahiskan students studying at Turkish universities have problems or needs related to immigration whereas some of them have problems or needs related to be a foreign student in higher education. Determining the psychological status and needs of these students are important for planning and implementing counseling and guidance services in higher education.

Life satisfaction is among the important concepts in this context, since research findings show the importance evaluating life satisfaction as an adjustment indicator after migration (Ward and Rana-Deuba, 1999) and 
the importance of life satisfaction in university years (Diener, 2000). Moreover, results of several studies indicated the possibility to obtain a number of positive psychological, social, physical, and academic outputs with an increase in one's life satisfaction (e.g., Diener, 1994; Myers and Diener, 1995; Roysamb, Tambs, Reichborn-Kjennerud, Neale and Harris, 2003; Staw, Sutton and Pelled, 1994; Yetim, 2003).

In this regard, the purpose of this study was to contribute to possible guidance and counseling interventions by examining the relationship between life satisfaction of Ahiska students in Turkey with various demographic variables, as gender, the starting level of education in Turkey, the country in which the family resides, the nationality of people who spend time outside the family, the length of their stay in Turkey. With this purpose, first, the validity and reliability of the SWLS that previously validated on Turkish university students were examined for Ahiska students attending at Turkish universities. Afterwards, the life satisfaction levels of the students compared according to demographic variables.

Data were collected from 307 (152 female, 154 male) students attending at 15 different Turkish state-funded universities, in the spring semester of 2018-2019 academic year. Students were in the age range of 17-35 with a mean of 21.45, and a standard deviation of 2.46.

The Satisfaction With Life Scale (SWL) was developed by Diener et al (1985) and a Personal Information Form developed by the researchers were used in data collection. The study data were analyzed using the AMOS 23 and SPSS 22 package softwares. Descriptive statistics were primarily calculated. Confirmatory Factor Analyses (CFA) was used to provide evidence of construct validity of the SWLS for Ahiskan students. Cronbach's alpha coefficient and item-total correlations were calculated to provide reliability evidence of the scale. Then, a series of independent samples t-test and analysis of variance (ANOVA) were run to compare independent groups for life satisfaction. Additionally, Pearson Product Moments correlation coefficient was calculated to investigate the relationships between variables. The analyses were based on $p<.001$ and $p<.01$ significance levels.

Results of CFA revealed that the SWLS showed a good fit to the original 5 item model for Ahiska students $(\chi 2 / \mathrm{df}=2.87 ; \mathrm{GFI}=.99 ; \mathrm{CFU}=.98$; $\mathrm{NFI}=.97 ; \mathrm{AGFI}=.95 ; \mathrm{RMSEA}=.04)$. Additionally, Cronbach's alpha 
coefficient ( $\alpha=.68)$ above the cutoff .60 (Y1ld1z and Uzunsakal, 2018) and item-total correlations above the cuttoff .30 (Büyüköztürk, 2004) showed that the SWLS has good internal consistency for these students.

Results of analyses conducted to compare the life satisfaction levels of Ahiskan students according to demographic variables revealed that there was no significant difference on the life satisfaction levels of the students in terms of gender, the country of residence of the family, and the nationality of people who spend time outside the family members. Ahiska students who started schooling in Turkey at elementary level scored significantly higher on the SWLS than students started schooling at middle and high school. Finally, life satisfaction was not significantly correlated with length of stay in Turkey.

\section{Kaynakça / References}

Agara, İ. (2004). Ahıska Türkleri (Sürgününün 60. Yılı Anısına) insanlık dramı. İzmir Ahıska Türkleri Kültür ve Dayanışma Derneği, İzmir: Karaca Matbaası Yayınları.

Akıncı, B. Nergiz, A. ve Gedik, E. (2015). Uyum süreci üzerine bir değerlendirme: Göç ve toplumsal kabul. Göç Araştırmaları Dergisi, 2 (1), 58-83.

Aslan, K. (1995). Ahıska Türkleri. Ankara: Ahıska Türkleri Kültür ve Dayanışma Derneği Yayını, No:1.

Bahar, H. H. ve Yılmaz, O. (2018). Ahıska, göç ve eğitim, Eğitimde Nitel Araşttrmalar Dergisi, 6 (2), 238-257.

Bayraktar, R. (1999). Ahıska (21. Yüzyılda İnsanlık Dramı). İstanbul: İhlas Matbaacilik.

Berry J. W. (1997). Immigration, acculturation and adaptation. Applied Psycholog: An International Review, 46(1), 5-34.

Bilge, F., Dost, T, M., ve Çetin, B. (2014). Lise öğrencilerinde tükenmişliği ve okul bağlılı̆̆ını etkileyen faktörler: çalışma alışkanlıkları, yetkinlik inancı ve akademik başarı. Kuram ve Uygulamada Eğitim Bilimleri, 14(5), 1709-1727.

Bingöl, A. S. ve Özdemir, M. Ç. (2014). Almanya ve Hollanda'da Türk göçmen işçi çocuklarına uygulanan eğitim politikaları. Türk Ĕ̆itim Bilimleri Dergisi, 12 (2), 134-157. 
Börü, N. ve Boyacı, A. (2016). Göçmen öğrencilerin eğitim-öğretim ortamlarında karşılaştıkları sorunlar: Eskişehir ili örneği. Turkish Studies, 11 (14), 123-158.

Büyüköztürk, Ş. (2004). Veri analizi el kitabı. Ankara: Pegem Yayıncılık.

Çalışkan, N., ve Ayık, A. (2015). Okul aile birliği ve velilerle iletişim. Ahi Evran Üniversitesi Sosyal Bilimler Enstitüsü Dergisi, 1(2), 69-82.

Çokuluk, Ö., Şekercioğlu, G. ve Büyüköztürk, Ş. (2010). Sosyal bilimler için çok değişkenli istatistik. Ankara: Pegem Akademi.

Dağll, A. ve Baysal, N. 2016, Yaşam doyumu ölçeği'nin Türkçeye uyarlanması: Geçerlik ve güvenirlik çalışması. Elektronik Sosyal Bilimler Dergisi, 15(59), 1250-1262.

Diener E, Emmons R A, Larsen R J ve Griffin S (1985) The satisfaction with life scale. Journal of Personality Assessment, 49, 71-75.

Diener, E. (1994). Assessing subjective well-being: Progress and opportunities. Social Indicators Research, 31(2), 103-157.

Diener, E. (2000). Subjective well-being: The science of happiness and a proposal for a national index. American Psychologist, 55 (1), 34-43.

Diener, E., Oishi, S. ve Lucas, R. E. (2003). Personality, culture, and subjective well-being: Emotional and cognitive evaluations of life. Annual Review of Psychology, 54(1), 403-425.

Dursun, S. ve Oğuz Duran, N. (2019). Türk üniversitelerindeki Ahıskalı öğrencilerin psikolojik dayanıklılık düzeylerinin bazı demografik değişkenler açısından incelenmesi. Sosyal Bilimler Dergisi/The Journal of Social Sciences, 6(41), 435-450.

Ganiyeva, S. (2012). Ahıska Türklerinin Türkiye'ye göç etmesi ve Türk vatandaşlığına alınması ile ilgili hukuki sorunlar. Selçuk Üniversitesi Hukuk Fakültesi Dergisi, 20 (1), 177-199.

Gündoğar, D., Sallan-Gül, S., Uskun, E., Demirci, S. ve Keçeci, D. (2007). Üniversite öğrencilerinde yaşam doyumunu yordayan etkenlerin incelenmesi. Klinik Psikiyatri Dergisi, 10 (1), 14-27.

Huebner, E. S. (2004). Research on assesment of life satisfaction of children and adolescents. Social Indicators Research, 66, 3-33.

Ilgar, M. Z. ve Ilgar, S. C. (2015). Göç ve göçmenliğin psikolojik yansımalarıvatansız vatandaş olmak. K.Canatan ve diğerleri (Ed.). Disiplinlerarası Göç ve Göç Politikaları Sempozyumu (s. 159-178) içinde. İstanbul: Sebahattin Zaim Üniversitesi Yayınları. 
Kaştan, Y. (2015). Türkiye göç yaşamış çocukların eğitim sürecinde karşılaşılan problemler. Uluslararası Sosyal ve Eğitim Bilimleri Dergisi, 4 (2), 216229.

Kemal, N. ve Oğuz Duran, N. (2019). Türkiye'de yükseköğretimdeki Ahıskalı öğrencilerin mutluluk ve psikolojik sağlamlık düzeylerinin bazı demografik değişkenler açısından incelenmesi. Eğitim Bilimleri ve Sosyal Bilimler Sempozyumu, Nevşehir, s.104.

Kermen, U., İlçin Tosun, N. ve Doğan, U. (2016). Yaşam doyumu ve psikolojik iyi oluşun yordayıcısı olarak sosyal kaygı. Eğitim Kuram ve Uygulama Araştırmaları Dergisi, 2 (2), 20-29.

Kıncal, R. Y. (1999). Ailenin eğitimsel fonksiyonları. Erzurum: Atatürk Üniversitesi Yayınları.

Köker, S. (1991). Normal ve sorunlu ergenlerin yaşam doyumu düzeyinin karşılaştırılması. Yayımlanmamış Yüksek Lisans Tezi, Ankara Üniversitesi, Sosyal Bilimler Enstitüsü, Ankara.

Mayungbo, O.A. (2016). Gender differences, self esteem and life satisfaction. African Journal for the Psychological Study of Social Issues, 19(1), 1-11.

Moksnes ,U.K., ve Espnes,G.A.(2013).Self-esteem and life satisfaction in adolescents - gender and age as potential moderators. Quality of Life Research, 22, 2921-2928.

Myers, D. G. ve Diener, E. (1995). Who is happy? Psychological science, 6(1), 1019.

Nicholai, S. ve Triplehorn,C. (2003). The role of education in protecting children in conflict. Humanitarian Practice Network, 42, 1-3.

Polat Uluocak, G. (2009). İç göç yaşamış ve yaşamamış çocukların okulda uyumu. Dokuz Eylül Üniversitesi Buca Ĕ̆itim Fakültesi Dergisi, 26,35-44.

Roysamb, E., Tambs, K., Reichborn-Kjennerud, T., Neale, M. C. ve Harris, J. R. (2003). Happiness and health: environmental and genetic contributions to the relationship between subjective well-being, perceived health, and somatic illness. Journal of Personality and Social Psychology, 85(6), 1136-1146.

Schermelleh-Engel, K., Moosbrugger, H., ve Müller, H. (2003). Evaluating the fit of structural equation models: Tests of significance and descriptive goodness-of-fit measures. Methods of Psychological Research Online, 8(2), 23-74. 
Seferov, R. ve Akış, A. (2008) Sovyet döneminden günümüze Ahıska Türklerinin yaşadıkları coğrafyaya göçlerle birlikte genel bir bakış. Türkiyat Araştırmaları Dergisi, 24, 393-411.

Sümer, N. (2000). Yapısal eşitlik modelleri: Temel kavramlar ve örnek uygulamalar. Türk Psikoloji Yazıları. 3 (6), 49-74.

Staw, B. M., Sutton, R. I. ve Pelled, S. H. (1994). Employee positive emotions and favorable outcomes at the workplace. Organization Science, 5(1), 51-71.

Şeker, B. ve Sirkeci, İ. (2014). Birleşik Krallık'daki Türkiye kökenli kadınlarda yaşam doyumu: Kimlik, kültürleşme ve ayrımcllık. Türk Psikoloji Yazıları, 17 (34), 69-81.

Şahin, A. (2018). Üniversite öğrencilerinde bilinçli farkındalık ile yaşam doyumu ve iyi oluş arasındaki ilişkiler. Yüksek Lisans Tezi, Üsküdar Üniversitesi Sosyal Bilimler Enstitüsü, İstanbul.

Tezcan, M. (1994). Ülkemizde göç ve eğitim sorunları. Ankara Üniversitesi Ĕ̆itim Bilimleri Fakültesi Dergisi, 27 (1), 61-67.

UNESCO. (2011). The hidden crisis: Armed conflict and education (EFA Global Monitoring Report 2011). Paris: UNESCO. Erişim adresi: http://unesdoc.unesco.org/images/0019/001907/190743e.pdf

Vedder, P., Van de Vijver, F. ve Liebkind, K. (2006). Predicting immigrant youths' adaptation across countries and ethnocultural groups. J. W. Berry, J. S. Phinney, D. L. Sam ve P. Vedder, (Ed.), Migrant youth in cultural transition: Acculturation, identity, and adaptation across national contexts içinde (143-166). Hamwah, NJ: Lawrence Erlbaum.

Verkutyen,M. (2008). Intergroup structure and identity management among ethnic minority and majority groups: The interactive effects of perceived stability, legitimacy, and permeability. European Journal of Social Psychology, 38 (1), 106-127.

Victor, C., Scambler, S., Bond, J. ve Bowling, A. (2000). Being alone in later life: Loneliness, social isolation and living alone. Reviews in Clinical Gerontology, 10 (4), 407-417.

Ward, C. ve Rana-Deuba, A. (1999). Acculturation and adaptation revisited. Journal of Cross-Cultural Psychology, 30(4), 422-442.

Yetim, U. (2003). The impacts of individualism/collectivism, self-esteem, and feeling of mastery on life satisfaction among the Turkish university students and academicians. Social Indicators Research, 61(3), 297-317. 
Yıldız ve Uzunsakal (2018). Alan araştırmalarında güvenilirlik testlerinin karşılaştırılması ve tarımsal veriler üzerine bir uygulama. Uygulamalı Sosyal Bilimler Dergisi, 1, 14-28.

Yılmaz, A. ve Mustafa, R. (2014). 1992 sonrası Türkiye'ye göçen Ahıska Türklerinin göç, iskân ve uyum sorunlarına ilişkin bir araştırma, Bursa örneği. Studies of Ottoman Domain, 4(6), 1-19.

Yıldırım, K. (2007). Göçün aile üzerindeki etkisi. Z. Dilek ve diğerleri (Ed.), 38. ICANAS-Uluslararası Asya ve Kuzey Afrika Çalışmaları KongresiKentleşme Sorunları ve Çözümleri (s. 961-974) içinde. Ankara: Atatürk Kültür, Dil ve Tarih Yüksek Kurumu Yayınları.

Zeyrek, Y. (2001). Ahıska Bölgesi ve Ahıska Türkleri. Ankara. Bizim AHISKA (2005-2006): Üç Aylık Kültür Dergisi. Uluslararası Ahıska Türk Dernekleri Federasyonu'nun Yayın Organı, Sayı: 1-6, Ankara: Kozan Ofset Yayınları.

\section{Kaynakça Bilgisi / Citation Information}

Kazımoğlu, M. ve Oğuz-Duran, N. (2019). Türkiye'de üniversite öğrenimi gören Ahıskalı öğrencilerin yaşam doyumlarının demografik değişkenler açısından incelenmesi. OPUS-Uluslararası Toplum Araştırmaları Dergisi, 14(20), 1070-1094. DOI: 10.26466/opus. 612655 